\title{
Salts Waters and Biofertilizers in Jackfruit Seedlings Formation
}

\author{
Francisco de O. Mesquita $\mathrm{II}^{1}$, Lourival F. Cavalcante ${ }^{2}$, Jackson de M. Alves ${ }^{3}$, Valéria F. de O. Sousa ${ }^{4}$, \\ Sebastião de O. Maia $\mathrm{Jr}^{5}$, Rafael O. Batista ${ }^{6}$, Reinaldo F. Medeiros ${ }^{7} \&$ Francisco R. de Azevedo ${ }^{8}$ \\ ${ }^{1}$ Department of Agronomy, Federal University of Cariri, Crato, CE, Brazil \\ ${ }^{2}$ Department of Soil and Rural Engineering, Federal University of Paraiba, Areia, PB, Brazil \\ ${ }^{3}$ Department of Exact and Agrarian Science, State University of Paraiba, Catolé do Rocha, PB, Brazil \\ ${ }^{4}$ Department of Agronomy, Federal University of Campina Grande, Campina Grande, PB, Brazil \\ ${ }^{5}$ Department of Agricultural Science, Federal University of Alagoas, Rio Largo, AL, Brazil \\ ${ }^{6}$ Department of Environmental and Social Sciences, Federal University of the Semi-Arid, Mossoró, RN, Brazil \\ ${ }^{7}$ Department of Course Technical in Agriculture, Federal Institute of Education, Science and Technology, Lagoa \\ da Confusão, TO, Brazil \\ ${ }^{8}$ Department of Entomology, Federal University of Cariri, Crato, CE, Brazil \\ Correspondence: Francisco de O. Mesquita II, Department of Agronomy, Federal University of Cariri, Crato, CE, \\ CEP: 63.133-520, Brazil. Tel: 55-88-999-436-685. E-mail: mesquitaagro@yahoo.com.br
}

Received: November 11, 2018

doi:10.5539/jas.v11n3p396
Accepted: December 14, $2018 \quad$ Online Published: February 15, 2019

URL: https://doi.org/10.5539/jas.v11n3p396

The research was financed by the National Council for Technological Development Scientific (CNPq) and Higher Education Personnel Coordination (CAPES).

\begin{abstract}
The salinity is considered one of the main obstacles to agriculture worldwide, constituting one of the limiting factors to the growth and development of the plants. The objective of this study was to evaluate the effects of salinity of irrigation water in the formation of seedlings two varieties of jackfruits, and with the application of common bovine biofertilizer and chemically enriched bovine biofertilizers. In this sense, an experimente was carried in greenhouse conditions, in the period from October 2015 to February 2016, in Areia County, Paraiba State, Brazil. The substrate used was a material collected of the first $10 \mathrm{~cm}$ of depth of a Dystrophic Regolitic Entisol. The experimental design was completely randomized in a factorial scheme $5 \times 3 \times 2$, corresponding to levels of irrigation water saline of $0.5 ; 1.0 ; 2.0 ; 3.0$ and $4.0 \mathrm{dS} \mathrm{m}^{-1}$, in soil without and with common bovine biofertilizer and enriched biofertilizer, tested with two varieties of jackfruit (jack-soft and jack-hard), and with six replicates. The biofertilizer after dilution in non-saline water $\left(0.5 \mathrm{dS} \mathrm{m}^{-1}\right)$, in proportion of $1: 3$, where was applied once to $10 \%$ of the substrate volume, two days before sowing. The increment of irrigation water salinity inhibited alls variables studied in the jackfruits plants, but with less intensity in the treatments with bovine common biofertilizer.
\end{abstract}

Keywords: Artocarpus heterophyllus, Artocarpus brasiliensis, organic bovine compound, sanilization, varieties of jackfruits

\section{Introduction}

The jackfruit (Artocarpus heterophyllus Lam.) is a tree of the family Moraceae, originating from India, present in all the tropical regions of the world and, is considered as an exotic and spontaneous species (Lorenzi et al., 2006; Santos et al., 2012). It was introduced in Brazil in the middle of the 17th century and by its expressiveness, is widely cultivated in domestic orchards of all the tropical regions of the country with great popularity and consumption (Chooklin et al., 2014). However, there is a challenge, mainly due to the difficulty in the production of seedlings (Abd El-Zaher, 2008).

The jackfruit has great economic importance, because besides its fruits is also used the wood, leaves and látex (Prakash et al., 2009, p. 353). Two varieties of the genre Artocarpusse emphasize by expressiveness, which are 
successful in Brazilian lands, among these, the hard jackfruit with berries of rigid consistency, large fruits and the jackfruit, whose fruits are smaller and have a more pasty consistency (Baliga et al., 2011).

Currently, the demand for the acquisition of high quality seedlings with well defined agronomic characteristics is increasing, aiming to improve the knowledge of the multiplication process, and so, to develop and adapt propagation technologies for this fruitful species. However, especially in arid and semi-arid regions, where water scarcity has become a preponderant factor, the production of seedlings is performed using groundwater, which in most cases contains high concentrations of soluble salts, impairing the germination and growth of the same (Oliveira et al., 2018, p. 625).

The salt water has hindered the agricultural activity by both the direct effects on the plant and its accumulation in the superficial layers of the soil. The effects of salinity are related to decreased osmotic potential, reducing the availability of water to vegetables, at the toxic effect of specific ions, such as $\mathrm{NaCl}$ ions, and the nutritional effect (Epstein \& Bloom, 2006; Munns \& Tester, 2008). Therefore, as the jackfruit does not present tolerance to the saline stress, however, their sensitivity may be even greater in the initial development phase (Morais et al., 2012). With this, besides the care with the quality of the water, special attention should also be given to the substrate. This should be of good quality, with nutrients in adequate amounts and preferably with mechanisms of controlled release, avoiding losses by leaching and volatilization (Simões et al., 2012, p. 97).

In this context, the need arises for the adoption of crop technologies that attenuate the deleterious effects of excess salts in the irrigation water during the whole phase of crop growth, especially during emergence and seedling formation. Among the materials used, we highlight the biofertilizer of bovine manure and the humic substances under irrigation with saline water, these inputs provide greater osmotic adjustment between the roots and the soil solution, minimizing the drasticity of the toxic effects of the salts on the plants (Aydin et al., 2012), thereby increasing the efficiency of water and nutrient uptake and, consequently, stimulating plant growth (Matsi et al., 2015; Oliveira et al., 2017).

Some studies show the positive action of the biofertilizers in partially attenuating the effects of water salinity on the formation of seedlings of some crops, such as guava (Cavalcante et al., 2010), of the yellow passion fruit (Mesquita et al., 2012) and oiticica (Diniz Neto et al., 2014), due to the presence of humic substances, contained in the organic inputs, provide greater osmotic regulation between root and soil solution, provide greater osmotic regulation between root and soil solution, and decrease the intensity of the toxic effects of the salts to the growth of the plants (Aydin et al., 2012). That way, It's was aimed to evaluate the effects of salinity of irrigation water on the formation of two varieties of jackfruit and with the application of common and enriched bovine biofertilizers.

\section{Material studied}

\subsection{Characterization of the Study Area}

The experiment with seedling of jackfruit was developed in the period from October/2015 to February/2016 in protected environment, in the Center of Agrarian Sciences, from Federal University of Paraiba, Areia county, States Paraiba, Brazil. The region has the geographic coordinates with latitude $6^{\circ} 58^{\prime} \mathrm{S}$ and longitude of $35^{\circ} 41^{\prime} \mathrm{W}$ and altitude of $575 \mathrm{~m}$. According to Köppen's classification, the climate of the region, is of type As'. The rainy season is concentrated in the period from March to July with average rainfall of $1.400 \mathrm{~mm}$ per year. The average air temperature is around $23{ }^{\circ} \mathrm{C}$.

The substrate used was a sandy-textured Regolitic Neossolo, no saline (Embrapa, 2013), submitted to laboratory analysis to determine the physical and chemical attributes regarding fertility, according to Embrapa (2011) and salinity (Richards, 1954), as indicate in Table 1. 
Table 1. Physical and chemical characterization of soil as to fertility and salinity in layer of $0-20 \mathrm{~cm}$

\begin{tabular}{|c|c|c|c|c|c|}
\hline Physical Attributes & Value & Fertility attributes & Value & Salinity attributes & Value \\
\hline $\mathrm{SD}\left(\mathrm{g} \mathrm{cm}^{-3}\right)$ & 1.51 & pH em água $(1: 2,5)$ & 6.70 & $\operatorname{SEEC~}\left(\mathrm{dS} \mathrm{m}{ }^{-1}\right)$ & 0.85 \\
\hline $\mathrm{DP}\left(\mathrm{g} \mathrm{cm}^{-3}\right)$ & 2.76 & $\mathrm{OM}\left(\mathrm{g} \mathrm{Kg}^{-1}\right)$ & 13.58 & $\mathrm{pH}$ & 6.85 \\
\hline $\mathrm{TP}\left(\mathrm{m}^{3} \mathrm{~m}^{-3}\right)$ & 0.46 & $\mathrm{P}\left(\mathrm{mg} \mathrm{dm}^{-3}\right)$ & 22.46 & $\mathrm{Ca}^{2+}\left(\mathrm{mmol}_{\mathrm{c}} \mathrm{L}^{-1}\right)$ & 2.44 \\
\hline Sand $\left(\mathrm{g} \mathrm{kg}^{-1}\right)$ & 869 & $\mathrm{~K}^{+}\left(\mathrm{mg} \mathrm{dm}^{-3}\right)$ & 127 & $\mathrm{Mg}^{2+}\left(\mathrm{mmol}_{\mathrm{c}} \mathrm{L}^{-1}\right)$ & 1.47 \\
\hline Silt $\left(\mathrm{g} \mathrm{kg}^{-1}\right)$ & 69 & $\mathrm{Ca}^{2+}\left(\mathrm{cmol}_{\mathrm{c}} \mathrm{dm}^{-3}\right)$ & 1.48 & $\mathrm{Na}^{+}\left(\mathrm{mmol}_{\mathrm{c}} \mathrm{L}^{-1}\right)$ & 4.41 \\
\hline clay $\left(\mathrm{g} \mathrm{kg}^{-1}\right)$ & 98 & $\mathrm{Mg}^{2+}\left(\mathrm{cmol}_{\mathrm{c}} \mathrm{dm}^{-3}\right)$ & 1.46 & $\mathrm{~K}^{+}\left(\mathrm{mmol}_{\mathrm{c}} \mathrm{L}^{-1}\right)$ & 1.53 \\
\hline $\mathrm{CDW}\left(\mathrm{g} \mathrm{kg}^{-1}\right)$ & 12 & $\mathrm{Na}^{+}\left(\mathrm{cmol}_{\mathrm{c}} \mathrm{dm}^{-3}\right)$ & 0.76 & $\mathrm{Cl}^{-}\left(\mathrm{mmol}_{\mathrm{c}} \mathrm{L}^{-1}\right)$ & 6.62 \\
\hline $\mathrm{DF}(\%)$ & 80.45 & $\mathrm{H}^{+}+\mathrm{Al}^{3+}\left(\mathrm{cmol}_{\mathrm{c}} \mathrm{dm}^{-3}\right)$ & 2.65 & $\mathrm{CO}_{3}{ }^{2-}\left(\mathrm{mmol}_{\mathrm{c}} \mathrm{L}^{-1}\right)$ & - \\
\hline DI (\%) & 12.76 & $\mathrm{Al}^{3+}\left(\mathrm{cmol}_{\mathrm{c}} \mathrm{dm}^{-3}\right)$ & 0.00 & $\mathrm{HCO}_{3}^{-}\left(\mathrm{mmol}_{\mathrm{c}} \mathrm{L}^{-1}\right)$ & 1.81 \\
\hline $\mathrm{U}_{\mathrm{cc}}\left(\mathrm{g} \mathrm{kg}^{-1}\right)$ & 15.43 & SEB $\left(\mathrm{cmol}_{\mathrm{c}} \mathrm{dm}^{-3}\right)$ & 4.02 & $\mathrm{SO}_{4}^{2-}\left(\mathrm{mmol}_{\mathrm{c}} \mathrm{L}^{-1}\right)$ & 1.12 \\
\hline $\mathrm{U}_{\mathrm{pmp}}\left(\mathrm{g} \mathrm{kg}^{-1}\right)$ & 3.67 & $\mathrm{CEC}\left(\mathrm{cmol}_{\mathrm{c}} \mathrm{dm}^{-3}\right)$ & 6.67 & $\operatorname{SAR}\left(\mathrm{mmol} \mathrm{L}^{-1}\right)^{1 / 2}$ & 2.76 \\
\hline $\mathrm{AW}\left(\mathrm{g} \mathrm{kg}^{-1}\right)$ & 6.37 & $\mathrm{~V}(\%)$ & 60.26 & $\operatorname{ESP}(\%)$ & 5.27 \\
\hline
\end{tabular}

Note. $\mathrm{SD}=$ Soil Density; $\mathrm{PD}=$ Particle of Density; $\mathrm{TP}=$ Total porosity; $\mathrm{CDW}=$ Clay dispersed in water; $\mathrm{DF}=$ Degree of flocculation; DI = Dispersion index; $\mathrm{U}_{\mathrm{cc}}$ and $\mathrm{U}_{\mathrm{pmp}}=$ Respectively, humidity of the soil to the -0.01 and $-1.5 \mathrm{Mpa} ; \mathrm{AW}=$ Available water; $\mathrm{OM}=$ Organic matter; $\mathrm{SEB}=$ Sum of Exchangeable Bases $\left(\mathrm{Na}^{+}+\mathrm{K}^{+}+\mathrm{Ca}^{2+}+\right.$ $\left.\mathrm{Mg}^{2+}\right) ; \mathrm{CEC}=$ Cation exchange capacity $=\mathrm{SB}+\left(\mathrm{H}^{+}+\mathrm{Al}^{3+}\right) ; \mathrm{V}=$ Saturation value by bases $(100 \times \mathrm{SB} / \mathrm{CTC})$; SEEC $=$ Saturation extract electric conductivity; SAR $=$ Sodium adsorption Relation $=\mathrm{Na}^{+} \times\left[\left(\mathrm{Ca}^{2+}+\right.\right.$ $\left.\left.\mathrm{Mg}^{2+}\right) / 2\right]^{-1 / 2} ; \mathrm{ESP}=$ Exchangeable Sodium Percentage $\left(100 \times \mathrm{Na}^{+} / \mathrm{CTC}\right)$.

\subsection{Experimental Design}

The treatments were distributed in a completely randomized design and factorial scheme $5 \times 3 \times 2$, concerning the values of the salinity of water irrigation of $0.5 ; 1.0 ; 2.0 ; 3.0$ and $4.0 \mathrm{dS} \mathrm{m}^{-1}$, in soil without biofertilizer and with two types of biofertilizer: common biofertilizer and enriched chemically biofertilizer and two varieties of jackfruit Artocarpus heterophyllus and Artocarpus brasiliensis), with six repetitions.

\subsection{Salts Waters Preparation}

The electrical conductivity level of each type of water was obtained through of the dilution of dam water, strongly saline (CE $\left.14.6 \mathrm{dS} \mathrm{m}^{-1}\right)$, in non-saline water $\left(0.5 \mathrm{dS} \mathrm{m}^{-1}\right)$. The common biofertilizer was obtained by anaerobic fermentation of equal parts of non-saline and non-chlorinated water with fresh bovine manure from lactating cows for 30 days (Silva et al., 2007). The enriched biofertilizer was prepared with the same amounts of water and common biofertilizer, however, besides that, were added of $4 \mathrm{~L}$ of molasses, $8 \mathrm{~L}$ of bovine milk and 4 $\mathrm{kg}$ of agricultural gypsum, provided on a weekly basis in the proportions of 1:2:1.

\subsection{Preparation of the Biofertilizers (Common and Enriched)}

For the maintenance of each hermetically sealed system, where the end of a $4 \mathrm{~mm}$ diameter hose was connected to the upper base of the biodigester and the other end immersed in a vessel with water. The agricultural gypsum used contained $26 \% \mathrm{CaO}, 14.7 \% \mathrm{~S}$ and $5 \%$ moisture by mass (Leite et al., 2010). The chemical composition of irrigation water and of the biofertilizers tupeis in the liquid form (Table 2) was done using the methodologies suggested by Richards (1954). Before application of input, each type of biofertilizer was diluted in water in proportion of 1:3, applied once, two days before of the sowing, in volume equivalent at $10 \%$ of the substrate volume $(3.5 \mathrm{~L})$. 
Table 2. Characterization of irrigation water, of the common bovine biofertilizer and bovine biofertilizer enriched with milk, molasses and agricultural gypsum. Areia-PB, Brazil

\begin{tabular}{|c|c|c|c|}
\hline \multirow{2}{*}{ Componentes } & \multirow{2}{*}{ Water } & \multicolumn{2}{|c|}{ Biofertilizer } \\
\hline & & Common & Enriched \\
\hline $\mathrm{EC}\left(\mathrm{dS} \mathrm{m}^{-1}\right)$ & 0.59 & 3.59 & 6.28 \\
\hline $\operatorname{SAR}\left(\mathrm{mmol} \mathrm{L}^{-1}\right)^{1 / 2}$ & 2.63 & 1.55 & 2.20 \\
\hline $\mathrm{Ca}^{2+}\left(\mathrm{mmol}_{\mathrm{c}} \mathrm{L}^{-1}\right)$ & 1.37 & 9.43 & 20.48 \\
\hline $\mathrm{Mg}^{2+}\left(\mathrm{mmol}_{\mathrm{c}} \mathrm{L}^{-1}\right)$ & 0.83 & 7.21 & 13.82 \\
\hline $\mathrm{Na}^{+}\left(\mathrm{mmol}_{\mathrm{c}} \mathrm{L}^{-1}\right)$ & 2.56 & 3.32 & 9.51 \\
\hline $\mathrm{K}^{+}\left(\mathrm{mmol}_{\mathrm{c}} \mathrm{L}^{-1}\right)$ & 0.19 & 10.55 & 17.42 \\
\hline $\mathrm{Cl}^{-}\left(\mathrm{mmol}_{\mathrm{c}} \mathrm{L}^{-1}\right)$ & 2.28 & 20.12 & 27.93 \\
\hline $\mathrm{HCO}_{3}^{-}\left(\mathrm{mmol}_{\mathrm{c}} \mathrm{L}^{-1}\right)$ & 0.45 & 6.12 & 8.98 \\
\hline $\mathrm{CO}_{3}^{2-}\left(\mathrm{mmol}_{\mathrm{c}} \mathrm{L}^{-1}\right)$ & 0.00 & 0.00 & 0.00 \\
\hline $\mathrm{SO}_{4}^{2-}\left(\mathrm{mmol}_{\mathrm{c}} \mathrm{L}^{-1}\right)$ & 0.76 & 6.23 & 15.52 \\
\hline Classification & $\mathrm{C}_{1} \mathrm{~S}_{1}$ & $\mathrm{C}_{2} \mathrm{~S}_{1}$ & $\mathrm{C}_{2} \mathrm{~S}_{1}$ \\
\hline
\end{tabular}

Note. $\mathrm{EC}=$ Electric Conductivity; $\mathrm{SAR}=$ Sodium Adsorption Ratio $\left.=\mathrm{Na}^{+} \times\left[\left(\mathrm{Ca}^{2+}+\mathrm{Mg}^{2+}\right) / 2\right)\right]^{-1}$.

At the sowing were placed five seeds of jackfruits in each experimental unit with $92 \%$ viability. At the 15 days after emergence, was done the thinning of the seedlings, maintaining the most vigorous and the irrigation with each saline level was accomplished daily in a volume established according to the water requirement of the culture, ranging from 150 to $350 \mathrm{~mL}$ of water until the end of the experiment, respecting the conditions of the soil field capacity.

\subsection{Statistical Analysis}

The results were submitted to analysis of variance by the " $F$ " test, and when significant, the salinity levels of the water were submitted to the Polynomial Regression analysis, while the biofertilizers and the jackfruits varieties were compared by the Tukey $(\mathrm{p}<0.05)$ (Banzatto \& Kronka, 2008). For the data processing, the free version of the SISVAR software was used 5.6, Build 86-DEX-UFL Alivre (Ferreira, 2011).

\section{Results and Discussion}

The electrical conductivity of the saturation extract of the seedlings substrate, avaluated in treatments with jack-soft and hard-jack (Figures 1A and 1B), was influenced positively by the interaction salinity of the water $\mathrm{x}$ biofertilizantes $\times$ cultivars, expressing superiority in treatments with common bovine biofertilizer in both varieties of jackfruit.

The absence of the biofertilizer in the two varieties of the jackfruit, that is in variety 1 (jack-soft) and variety 2 (jack-hard), were found increases in the SEEC of 0.91 and $1.75 \mathrm{dS} \mathrm{m}^{-1}$ in the electrical conductivity of the water estimated of $0.5 \mathrm{dS} \mathrm{m}^{-1}$ reaching values of 4.66 and $4.71 \mathrm{dS} \mathrm{m}^{-1}$ in the electrical conductivity of the estimated maximum water of $4.0 \mathrm{dS} \mathrm{m}^{-1}$.
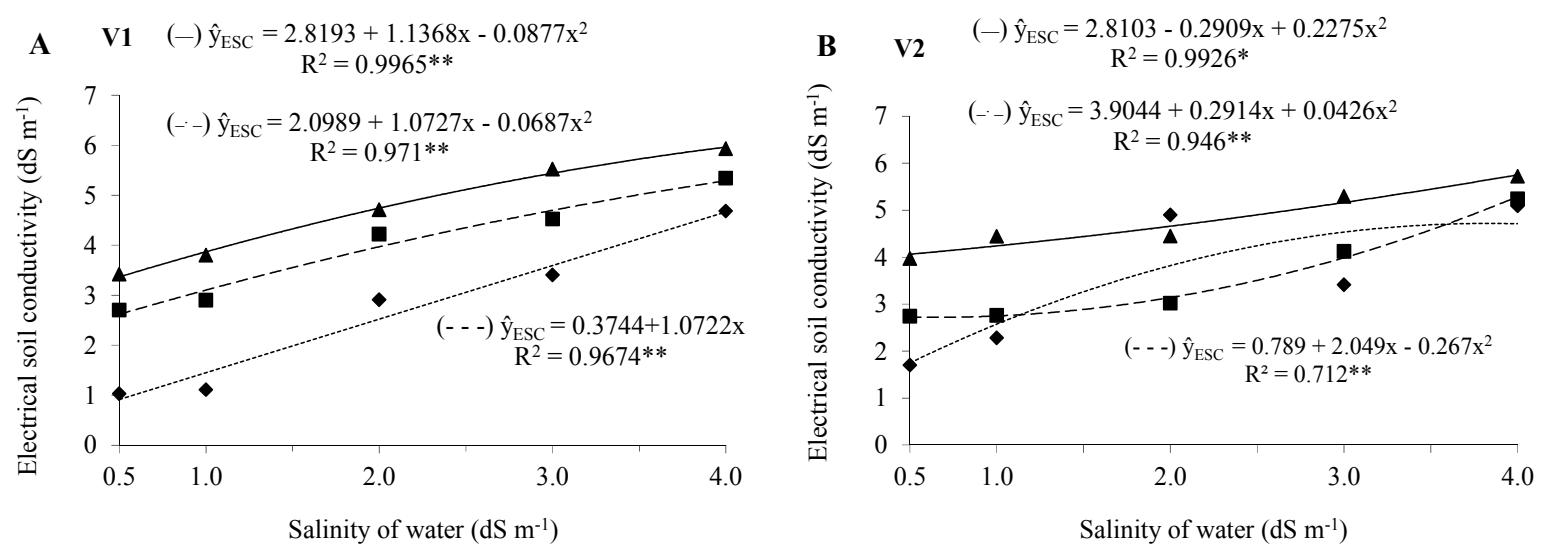
C V1

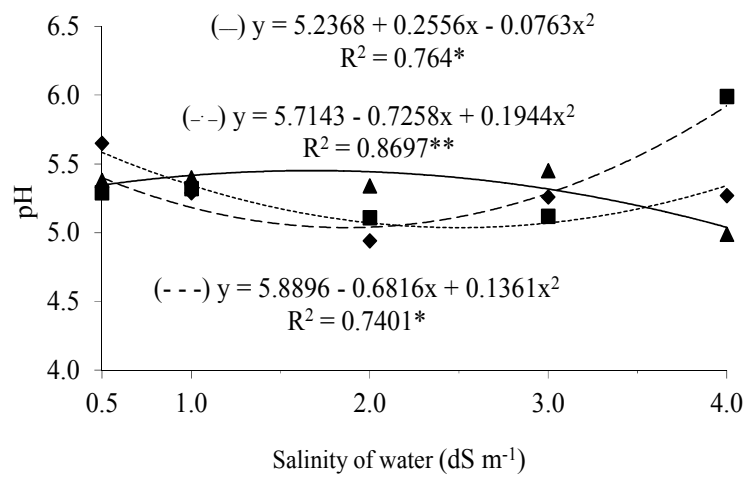

D V2 $(-) \hat{y}=-0.1746 x+5.6507$ $\mathrm{R}^{2}=0.7584 * *$

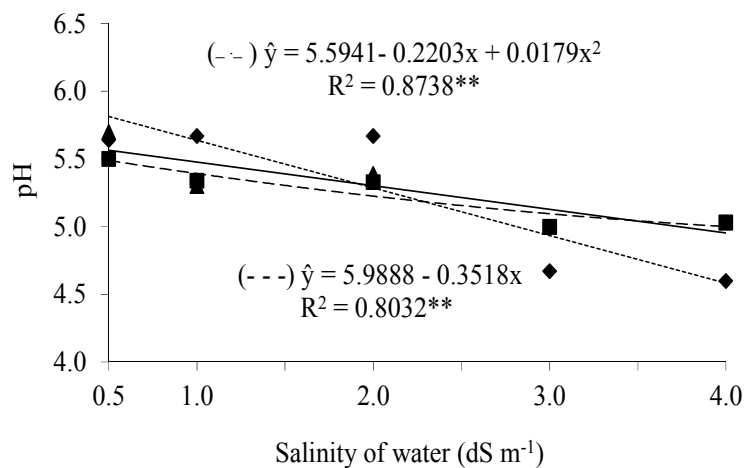

Figure 1. Saturain extract electric conductivity of the soil (SEEC) and $\mathrm{pH}$ of the solution soil cultivated with two varieties of jackfruit, V1 (jack-soft) and V2 (jack-hard) treated in soil without biofertilizer bovine (---), soil with bovine common biofertilizer (---) and with biofertilizer chemically enriched (-) under irrigation water salinity

In the soil with enriched biofertilizer, the substrates of the seedlings had their SEEC increased from 2.61 and $2.72 \mathrm{dS} \mathrm{m}^{-1}$ for 5.41 and $5.70 \mathrm{dSm}^{-1}$, respectively, in the varieties $\mathrm{V} 1$ and $\mathrm{V} 2$, referring to the electrical conductivity of the estimated maximum water of $4.0 \mathrm{dS} \mathrm{m}^{-1}$ (Figures 1A and 1B).This increase of the electrical conductivity in the substrate with biofertilizer in relation to the absent of this input, is due to the conductivity of the same, which at the moment of its application had a value of $3.59 \mathrm{dS} \mathrm{m}^{-1}$.

Regarding the enriched bovine biofertilizer, the conductivity of the substrate saturation extract was superior to the common biofertilizer with 12.67 and $8.90 \%$, in variety 1 (jack-soft) and variety 2 (jack-hard), in this order, in the electrical conductivity of $4.0 \mathrm{dS} \mathrm{m}^{-1}$, respectively (Figures 1A and 1B). Second Ayers and Westcot (1999), the jackfruits is considered sensitive to the effects of salts with waters that offer moderate restrictions (ECW > 2.55 $\mathrm{dS} \mathrm{m^{-1 }}$ ) or severe $\left(E C W>3.0 \mathrm{dS} \mathrm{m}^{-1}\right.$ ). Yet, according Rodrigues et al. (2017) these organic inputs, while providing an increase in the electrical conductivity of the substrate, stimulate the growth and production of vegetal biomass. The results are in agreement with Lima Neto et al. (2016), Carneiro et al. (2017) and Oliveira et al. (2017) when they noticed an increase in the concentration of salts of the soil with irrigation of waters with increasing salinity.

In variety 1 (Figures $1 \mathrm{~A}$ and $1 \mathrm{~B}$ ), the increase of the electrical conductivity in the irrigation water promoted decreases in $\mathrm{pH}$ of the substrate from $5.58 \%$ to $5.03 \%$ until the saline level of $2.5 \mathrm{dS} \mathrm{m}^{-1}$ showing a small increase from this level, in the absence of the application of the biofertilizer, in the same way that the use of the common biofertilizer provided a decline from $5.4 \%$ to $5.03 \%$ to the saline level of $1.87 \mathrm{dS} \mathrm{m}^{-1}$. However, the application of the common bovine biofertilizer favored quadratic behavior with a maximum point $1.67 \mathrm{dS} \mathrm{m}^{-1}$ corresponding to $5.45 \%$ of $\mathrm{pH}$ decreasing from this conductivity.

Similarly, there was a significant interaction effect for the hydrogen potential $(\mathrm{pH})$ of the substrate saturation extract for water salinity $\times$ cultivars $\times$ biofertilizers in the production of jackfruit seedlings (Figures 1C and 1D).

Whilst, the $\mathrm{pH}$ values were in the ideal range for the jack, as soon as it prefers soil $\mathrm{pH}$ around $5.0-7.5 \%$ (Elevitch \& Manner, 2006). The increase in $\mathrm{pH}$ with the use of the enriched biofertilizer is likely due to the composition of this constitutes of molasses, agricultural gypsum and milk, having a higher concentration at the moment of application of the anion $\mathrm{HCO}_{3}^{-}\left(8.98 \mathrm{mmol}_{\mathrm{c}} \mathrm{L}^{-1}\right)$ in relation to the common biofertilizer $\left(6.12 \mathrm{mmol}_{\mathrm{c}} \mathrm{L}^{-1}\right)$. According to Santos et al. (2016), the $\mathrm{pH}$ is high when there is low hydrogen ion concentration $\left(\mathrm{H}^{+}\right)$and high concentration of some anions as $\mathrm{OH}^{-}, \mathrm{CO}_{3}{ }^{2-}$ and $\mathrm{HCO}_{3}{ }^{-}$(Figure 1D). Second Castelo-Gutiérrez et al. (2016), this lower attenuation of the $\mathrm{pH}$ observed in the soil with application of organic treatments can be attributed to the basic levels of cations (Ca, $\mathrm{Mg}$ and $\mathrm{K}$ ) in these inputs (Figure 1C).

In V2, the hydrogen ionic potential behaved negatively linearly by increasing the electrical conductivity in irrigation water, with higher attenuations in the absence of $0.5 \mathrm{dS} \mathrm{m}^{-1}$. The biofertilizer equivalent to $21.18 \%$ among the lowest $\left(0.5 \mathrm{dS} \mathrm{m}^{-1}\right)$ and the biggest $\left(4.0 \mathrm{dS} \mathrm{m}^{-1}\right)$ level saline (Figures $1 \mathrm{C}$ and $\left.1 \mathrm{D}\right)$. It was verified that with the supply of the biofertilizer, both the common as enriched, it declined only around in $10 \%$ with increase of salinity in irrigation water up to $4.0 \mathrm{dS} \mathrm{m}^{-1}$. 
In regarding at the height of the jackfruit plants, it was verified a significant influence with salt water use, types of biofertilizers and varieties of jackfruit, with linear and quadratic reductions as a function of the addition of salts in the water. It was observed in variety 1 , in the substrate with rich biofertilizer, a decrease from 45.77 to $34.44 \mathrm{~cm}$, seeings with this, a percentage drop of $24.75 \%$ in growth in height. However, in the soil with common bovine biofertilizer, the seedlings of jackfruit had your height increased inversely proportional to the rich biofertilizer. This morphometric gain at the height of the seedlings was of order from 28.77 to $38.38 \mathrm{~cm}$, corresponding to the salinities estimated of 0.5 and $4.0 \mathrm{dS} \mathrm{m}^{-1}$, respectively (Figures 2A). Therefore, the use of the biofertilizer provided higher growth in height when compared to the treatment without the organic compound, however, in function of the salines levels in the water there were reductions differently from the treatment without organic fertilizer, possibly by the salts originating from the own input.

In variety 2 (Figures $2 \mathrm{~B}$ ), there were declines proportional to the increase of salts with both the common biofertilizer, how much with the use of the enriched biofertilizer, showing higher values with the use of biofertilizer enriched with a decrease of $22.39 \%$ between the highest and lowest saline level, in the same way, with the use of the common biofertilizer presenting a decrease of $16.75 \%$ and the treatment without use of the biofertilizer reduced $28.36 \%$, from the salinity threshold $2.04 \mathrm{dSm}^{-1}$.
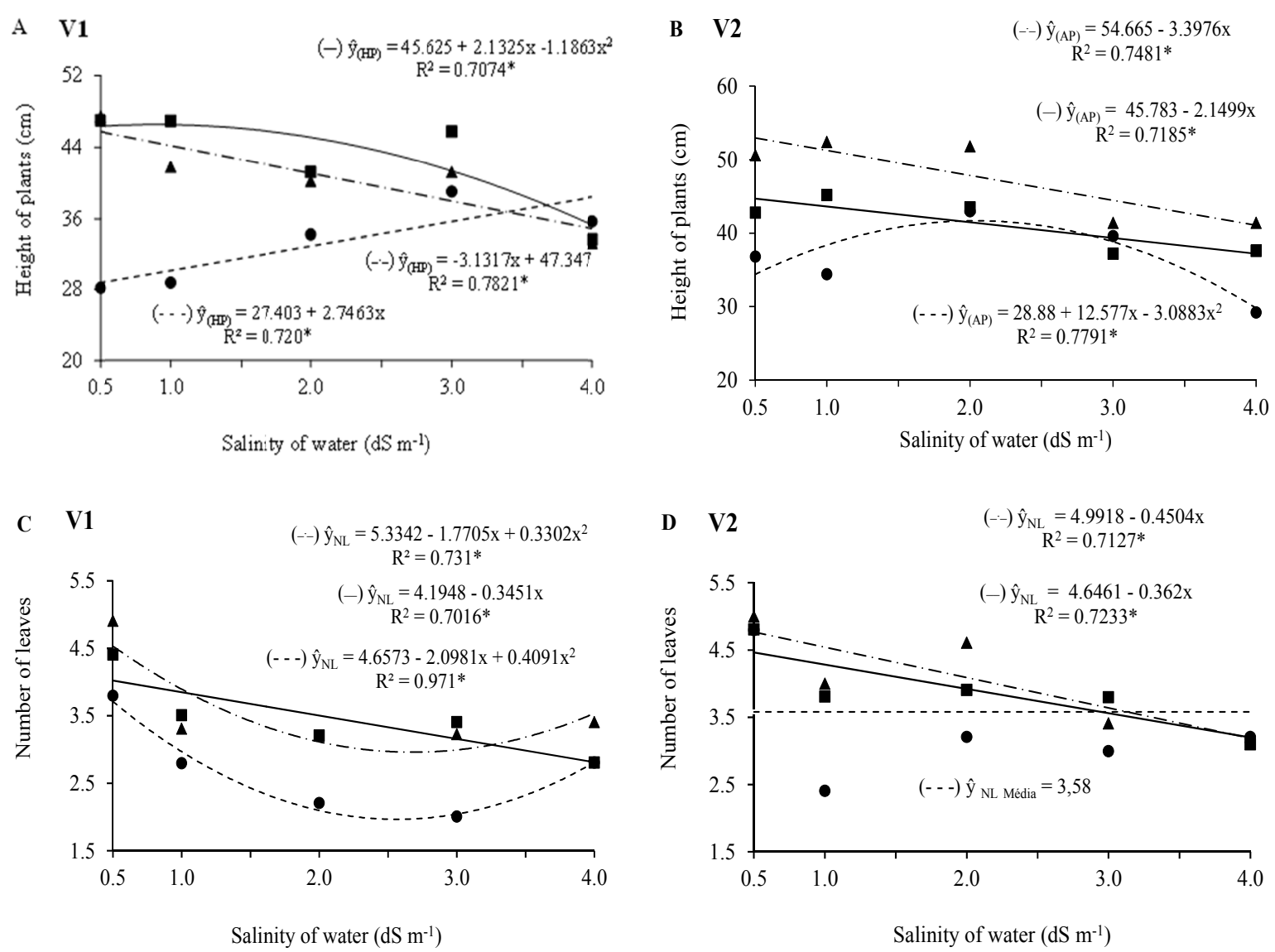

Figure 2. Height plants (HP) and leaves number (LN) referring to two varieties of jackfruit V1 (jack-soft) and V2 (jack-hard) treated in non-saline soil without bovine biofertilizer (---), with common biofertilizer (-- - ) and biofertilizer enriched chemically (-) under irrigation water saline

This positive effect with the use of bovine biofertilizer (Figure 2D), especially the enriched is due to being a source of fermented organic matter, which can stimulate the release of humic substances when applied to the soil causing an increase in the production of organic solutes, such as sugars, aminoacids free, proline, betaine and glycine, which affect positively the nutrition of the plant (Mesquita et al., 2015; Nascimento et al., 2016).

The salinity affected the growth of the plants, mainly in the initial phase of growth, as observed in guava seedlings (Cavalcante et al., 2010), papaya-Carica papaya (Sá et al., 2013; Lima Neto et al., 2016) and 
oiticica-Licania rigida (Diniz Neto et al., 2014). This is due to the fact that the saline stress limits the photosynthetic rate and stomatal conductance, which consequently decreases the rate of $\mathrm{CO}_{2}$ assimilation, compromising the plant growth (Freire et al., 2014; Melo Filho et al., 2017).

Similar to this study, Oliveira et al. (2017) observed in jackfruit seedlings that the height of the seedlings reduced with increasing water salinity from 0.3 to $4.0 \mathrm{dS} \mathrm{m}^{-1}$. These authors evaluated the possible mitigating effects of nitrogen sources on salinity, as as well was evaluating with the application of biofertilizers in this study, in which was observed the salinity mitigation on the height of the seedlings by the biofertilizers, mainly the common input, and in the variety V2 (Figure 2A and 2B). Noting these results, Rodrigues et al. (2017), observed in the Indian neem culture cultivated in saline soil under in the same conditions, that the use of common biofertilizer was better than that chemically enriched in the dry mass production of the leaves (Figures $2 \mathrm{C}$ and $2 \mathrm{D}$ ). In fact, the enriched biofertilizer increases the soil salinity profile as verified by Rodrigues et al. (2017) observing that the SEEC was of 5.98 and $7.26 \mathrm{dS} \mathrm{m}^{-1}$, respectively, in soils containing common and enriched biofertilizer (Figure 2B).

However, the two types of biofertilizers were able to attenuate the effects of the salts on growth of the seedlings of both varieties of jackfruit, for stand out at treatment in which biofertilizer the no was applied. It was also verified in mango plants and with the use of the inputs increased the soil salinity, minimized the effects of water salinity on plant growth-Morinda citrifolia (Rodrigues et al., 2017). On the other side, the lower efficiency of the enriched biofertilizer is due to its higher salinity promoted at the soil, as observed by the increase from the soil SEEC simultaneous to the increase of the salinity of the water when applied this input.

Regarding the number of leaves, we observed linear and quadratic behaviors in the V1 variety, respectively (Figure 2C), reaching an estimated minimum value of 4.01 (linear) versus 2.95 and 1.93 (quadratics), the number of leaves in the estimated electrical conductivities of 0.5 (lower value) and the threshold salinities 2.55 and 2.68 $\mathrm{dS} \mathrm{m} \mathrm{m}^{-1}$, respectively, with use in the order of the common biofertilizer, the rich and the absence of biofertilizer. At the same time, the use of the common biofertilizer declined from $4.02\left(0.5 \mathrm{dS} \mathrm{m}^{-1}\right)$ to $2.83\left(4.0 \mathrm{dS} \mathrm{m}^{-1}\right)$.

In the variety $\mathrm{V} 2$, the seedlings of jackfruit did not present significant adjustment for use of the common biofertilizer presenting an average of 3.58 leaves per plant, while that, use of the enriched biofertilizer declined by $34.58 \%$ until water conductivity of $3.5 \mathrm{dS} \mathrm{m}^{-1}$, and the common biofertilizer showed a decrease of $4.55(0.5$ $\left.\mathrm{dS} \mathrm{m} \mathrm{m}^{-1}\right)$ to $3.02\left(4 \mathrm{dS} \mathrm{m}^{-1}\right)$, equivalent to a reduction of $33.53 \%$ (Figure 2D).

The action of the types of biofertilizer for the number of leaves was different from the height of the seedlings, because although this, also decreased with the increase of the salinity of the water, it's was lower when a common biofertilizer was applied, in the two varieties of jackfruit, mainly in V1. This may have been due to the greater contribution of the common biofertilizer to the growth at the height of the seedlings, since as a strategy of acclimatization to saline stress, the plants tend to reduce the emission and expansion of the leaves, or energy expenditure on osmotic adjustment (Sá et al., 2013).

However, the enriched biofertilizer even providing the LN superior to the common and in the absence of biofertilizer with the increased salinity of the water, was the one that reduced, consequently, reflecting in the area and dry foliar mass. This indicates that the NL, although smaller with the use of the common biofertilizer, in the two varieties of jackfruit, was overcome by the smaller reduction in relation to the enriched, like the increase of the salinity.

The salinity of irrigation water regardless of the supply of biofertilizers interfered in the variety of jackfruit for the stem diameter (Figure 3A), where it was found that jack-soft (variety 1) did not have a significant influence on the electrical conductivity of the water, presenting a mean value of caulinar diameter of $4.60 \mathrm{~mm}$, but, the cultivar jack-hard (variety 2) behaved quadratically with maximum salinity point estimated of $1.75 \mathrm{dS} \mathrm{m}^{-1}$ corresponding to approximately $5.24 \mathrm{~mm}$ declining from this saline concentration. 

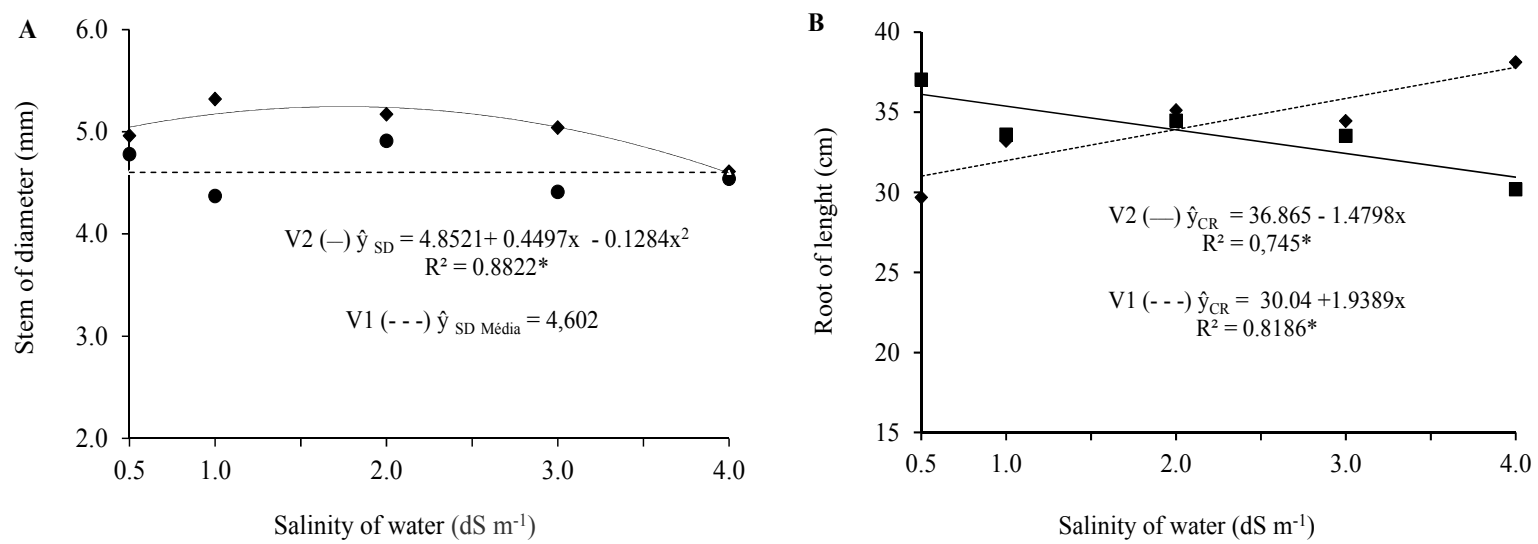

Figure 3. Stem diameter-SD (A) and root lenght-RL (B) two of varities of the jackfriut, jack-solf (---) and jack hard (-) under irrigation water salinity

According Elevitch and Manner (2006), the ideal stem diameter in the production of jackfruit seedlings is $9 \mathrm{~mm}$ with approximately 3 to 4 months of age, when they are imposed to favorable conditions. In the present study, were found inferior results, even in the treatment without the o use of saline water, perhaps due to the inferior experimental conduction time or the submitted conditions. According Taiz et al. (2017), this inhibition of the growth caused by the salinity is due to the osmotic effect, which promotes the physiological drought, as well as causes the toxic effect, resulting from the concentration of ions in the protoplasm (Figure 3A).

Yet, the addition of ions with elevated electrical conductivity and the decline of $\mathrm{pH}$ in the soil saturation extract may have affected the seedling in phase soil soluble by increasing of sodium in the soluble phase of the soil, restricting too much cations, thus providing nutritional imbalance and especially in inhibiting the absorption of some macronutrients such as calcium, magnesium and potassium (Pessoa et al., 2010). Comparatively, the effects of saline stress on the caulinar diameter differed from those recorded by Oliveira et al. (2017) in jackfruit seedling of the veriety solf wich showed declines of $5.62 ; 4.40$ and $4.52 \mathrm{~mm}$, resulting in loss of 1.06; 11.44 and $20.42 \%$, respectively, between plants irrigated with water of $1.0 ; 2.0 ; 3.0$ and $4.0 \mathrm{dS} \mathrm{m}^{-1}$ compared to those irrigated with lower levels of saline water $\left(0.3 \mathrm{dS} \mathrm{m}^{-1}\right)$ according with (Figures $3 \mathrm{~A}$ and $3 \mathrm{~B}$ ).

The salinity of the irrigation water interfered significantly in the root length of the jackfruit cultivars (Figure 3B). It was verified that the seedlings of the variety V1 and V2 presented behaviors inversely proportional to the root length. Comparatively the two varieties of jackfruit with the saline increment of the irrigation water, statistically, the variety 1 (jack-solf), we obtained increment of $12 \%$ in root length in relation to variety 2 (jack-hard), possibly due to the genetic divergence between the cultivars. Also, it can be observed that the use of water for irrigation with different saline compositions increased by $3.58 \%$ and $18.31 \%$, respectively.

Regarding the root length in the interaction cultivars vs water salinity (Figure 3B), the seedling of jackfruit presented very distinct linear behavior by the use of waters of different saline compositions, where variety 1 presented the root growth inversely proportional to variety 2 with 81 and $74 \%$ of reliability, respectively. The variety 1 (jack-solf) presented a linear increase proportional to the increase of salts in the irrigation water over the behavior of main root length, with an increase of $21.80 \%$, while the treatments tested with variety 2 (jack-hard) had a percentage of loss to $13.55 \%$ in this same saline range if compared to low salinity water $(0.5$ $\mathrm{dS} \mathrm{m}^{-1}$ ) demonstrating that this cultivar is more susceptible to salt stress compared to the other.

By the Figure 3A, the salt tolerance, although relatively low in most cultivated species, can occur with great genetic variability not only among species, but also among cultivars within the same species, such as occurred in this study (Ponte et al., 2011). These authors still denote that the inhibition in the root system of the plant occurs as a strategy to avoid contact direct with the salt in the substrate. The majority of fruits presented a detriment in growth with increased salts in the irrigation water, such as lemon-Citrus limon (Sá et al., 2017), papaya (Lima Neto et al., 2016) and guava-Psidiun guajava (Cavalcante et al., 2010).

These effects, are probably, due to the humic substances present in these organic compounds, which provides greater osmotic adjustment between the root and soil solution (Lima Neto et al., 2016), leading to decreased ion toxicity, such as $\mathrm{Na}^{+}$and $\mathrm{Cl}^{-}$(Munns \& Tester, 2008; Aydin et al., 2012) and increased efficiency in the absorption of water and essential nutrients (Cavalcante et al., 2010; Rodrigues et al., 2017), stimulating the growth of plants. Diniz Neto et al. (2014) also observed, in seedlings of oiticica, that the application of common 
biofertilizer reduced the deleterious effects of water salinity, noting the beneficial action of this organic input during the initial growth of the plants.

\section{Conclusions}

The biofertilizers did not eliminate, but they attenuated positively the degenerative effects of the excess of salts present in the irrigation water at the jackfruit plants.

The stem diameter, diameter main root and root length of the jackfruit seedling were higher in the substrates with biofertilizers.

The statistical superiority of all the variables studied indicates a positive action of the biofertilizers in reducing the saline effects of the irrigation water to the plants.

Soil salinity increased with salinity of water, but less affected the growth of plants in treatments with biofertilizers

\section{Acknowledgements}

The authors thank at the National Council for Technological Development Scientific (CNPq), the Higher Education Personnel Coordination (CAPES) and the Science Technology in Salinity National Institute (INCTSal), respectively, for the awarding of scientific initiation scholarships in undergraduate, postgraduate Master's degree, $\mathrm{PhD}$ and research productivity and financial aid to carry out the project activities.

\section{References}

Abd El-Zaher, M. H. (2008). Studies on Micro Propagation of Jackfruit 1-Behaviour of the Jackfruit Plants Through the Micropropagation Stages. World Journal of Agricultural Sciences, 4(2), 263-279.

Aydin, A., Kant, C., \& Turan, M. (2012). Humic acid application alleviate salinity stress of bean (Phaseolus vulgaris L.) plants decreasing membrane leakage. African Journal of Agricultural Research, 7(7), 1073-1086. https://doi.org/10.5897/AJAR10.274

Ayers, R. S., \& Westcot, D.W. A. (1999). A qualidade da água na agricultura (2nd ed., p. 153). Campina Grande: UFPB.

Baliga, M. S., Shivashankara, A. R., Haniadka, R., Dsouza, J., \& Bhat, H. P. (2011). Phytochemistry, nutritional and pharmacological properties of Artocarpus heterophyllus Lam (jackfruit): A review. Food Research International, 44(1), 1800-1811. https://doi.org/10.1016/j.foodres.2011.02.035

Banzatto, D. A., \& Kronka, S. N. (2008). Experimentação agrícola (4th ed., p. 247). Jaboticabal: UNESP.

Carneiro, M. A., Lima, A. M. N., Cavalcante, I. H. L., Cunha, J. C., Rodrigues, M. S., \& Lessa, T. B. S. (2017). Soil salinity and yield of mango fertigated with potassium sources. Revista Brasileira de Engenharia Agricola e Ambiental, 21(5), 310-316. https://doi.org/10.1590/1807-1929/agriambi.v21n5p310-316

Castelo-Gutiérrez, A. A., García-Mendívil, H. A., Castro-Espinoza, L., Lares-Villa, F., Arellano-Gil, M., Figueroa-López, P., \& Gutiérrez-Coronado, M. A. (2016). Residual mushroom compost as soil conditioner and bio-fertilizer in tomato production. Revista Chapingo Série Horticultura, 22(2), 83-94. https://doi.org/ 10.5154/r.rchsh.2015.06.012

Cavalcante, L. F., Vieira, M. S., Santos, A. F., Oliveira, W. M., \& Nascimento, J. A. M. (2010). Água salina e esterco bovino líquido na formação de mudas de goiabeira cultivar paluma. Revista Brasileira de Fruticultura, 32(1), 251-261. https://doi.org/10.1590/S0100-29452010005000037

Chooklin, C. S., Petmeaun, S., Maneerat, S., \& Saimmai, A. (2014). Isolation and characterization of a biosurfactant from Deinococcus caeni PO5 using jackfruit seed powder as a substrate. Universidade de Milan, 64(3), 1007-1020. https://doi.org/10.1007/s13213-013-0738-2

Diniz Neto, M. A., Silva, I. F., Cavalcante, L. F., Diniz, B. L. M. T., Silva, J. C. A., \& Silva, E. C. (2014). Mudas de oiticica irrigadas com águas salinas no solo com biofertilizante bovino e potássio. Revista Brasileira de Engenharia Agrícola e Ambiental, 18(1), 10-18. https://doi.org/10.1590/S1415-43662014000 100002

Elevitch, C. R., \& Manner, H. I. (2006). Artocarpus heterophyllus (jackfruit), ver. 1.1v. InC. R. Elevitch (Ed.), Species Profiles for Pacific Island Agroforestry (p. 17). Permanent Agriculture Resources (PAR), Hōlualoa.

EMBRAPA (Empresa Brasileira de Pesquisa Agropecuária). (2011). Manual de métodos de análise de solo (3rd ed., p. 230). Rio de Janeiro: EMBRAPA-Solos. 
EMBRAPA (Empresa Brasileira de Pesquisa Agropecuária). (2013). Sistema Brasileiro de Classificação de Solo (3rd ed., p. 353). Rio de Janeiro: EMBRAPA-Solos.

Epstein, E., \& Bloom, A. J. (2006). Nutrição mineral de plantas: Princípios e perspectivas (p. 403). Londrina: Editora Planta.

Embrapa (Empresa Brasileira de Pesquisa Agropecuária). (2013). Solos: Sistema Brasileiro de Classificação de Solo (3rd ed.). Rio de Janeiro, RJ.

Ferreira, D. F. (2011). Sisvar: A computer statistical analysis system. Ciência e Grotecnologia, 35(6), 1039-1042. https://doi.org/10.1590/S1413-70542011000600001

Freire, A. L., Ramos, C. L., Almeida, E. G., Duarte, W. F., \& Schwan, R. F. (2014). Study of the physicochemical parameters and spontaneous fermentation during the traditional production of yakupa, an indigenous beverage produced by Brazilian Amerindians. World Journal of Microbiology and Biotechnology, 30(2), 567-577. https://doi.org/10.1007/s11274-013-1476-0

Leite, E. M., Diniz, A. A., Cavalcante, L. F., Gheyi, H. R., \& Campos, V. B. (2010). Redução da sodicidade em um solo irrigado com a utilização de ácido sulfúrico e gesso agrícola. Caatinga, 23(2), 110-116.

Lima Neto, A. J., Cavalcante, L. F., Mesquita, F. O., Souto, A. G. L., Santos, G. P., Santos, J. Z., \& Mesquita, E. F. (2016). Papaya seedlings irrigation with saline water in soil with bovine biofertilizer. Chilean Journal of Agricultural Research, 76(1), 235-241.

Lorenzi, H., Sartori, S. F., Bacher, L. B., \& Lacerda, M. T. C. (2006). Frutas brasileiras e exóticas cultivadas: De consumo in natura (p. 672). São Paulo: Instituto Plantarum de Estudos da Flora.

Matsi, T. H. A. S., \& Lithourgidis, N. B. (2015). Effect o fliquid cattle manure on soil chemical properties and corn growth in Northern Greece. Experimental Agriculture, 51, 435-450. https://doi.org/10.1017/S00144 79714000404

Melo Filho, J. S., Véras, M. L. M., Alves, L. S., Silva, T. I., Gonçalves, A. C. M., \& Dias, T. J. (2017). Salinidade hídrica, biofertilizante bovino e cobertura vegetal morta na produção de mudas de pitombeira (Talisia esculenta). Revista Scientia Agraria, 18(3), 131-145. https://doi.org/10.5380/rsa.v18i3.54307

Mesquita, E. F., Sá, F. V. S., Bertino, A. M. P., Cavalcante, L. F., Paiva, E. P., \& Ferreira, N. M. (2015). Effect of soil conditioners on the chemical attributes of a saline-sodic soil and on the initial growth of the castor bean plant. Semina: Ciências Agrárias, 36(4), 2527-2538. https://doi.org/10.5433/1679-0359.2015v36n4p2527

Mesquita, F. O., Rebequi, A. M., Cavalcante, L. F., \& Luna Souto, A. G. (2012). Crescimento absoluto e relativo de mudas de maracujazeiro sob biofertilizante e águas salinas. Revista de Ciências Agrárias, 35(1), 222-239.

Morais, F. A., Góes, G. B., Costa, M. E., Melo, I. G. C., Veras, A. R. R., \& Cunha, G. O. M. (2012). Fontes e proporções de esterco na composição de substratos para produção de mudas de jaqueira. Revista Brasileira de Ciências Agrárias, 7, 784-789. https://doi.org/10.5039/agraria.v7isa2204

Munns, R., \& Tester, M. (2008). Mechanisms of Salinity Tolerance. Annual Review of Plant Biology, 59, 651-681. https://doi.org/10.1146/annurev.arplant.59.032607.092911

Nascimento, J. A. M., Cavalcante, L. F., Cavalcante, I. H. L., Pereira, W. E., Dantas, S. A. G., \& Medeiros, S. A. S. (2016). The impacts of biofertilizer and mineral fertilization on the growth and production of yellow passion fruit irrigated with moderately saline water. Ciencia e Investigación Agraria, 43(2), $253-262$. https://doi.org/10.4067/S0718-16202016000200008

Oliveira, F. I. F., Souto, A. G. L., Cavalcante, L. F., Medeiros, W. J. F., Medeiros, S. A. S., \& Oliveira, F. F. (2018). Biomass and chloroplast pigments in jackfruit seedlings under saline stress and nitrogen fertilization. Revista Caatinga, 31(3), 622-631. https://doi.org/10.1590/1983-21252018v31n310rc

Oliveira, F. I. F., Souto, A. G. L., Cavalcante, L. F., Medeiros, W. J. F., Bezerra, F. T. C., \& Bezerra, M. A. F. (2017). Quality of jackfruit seedlings under saline water stress and nitrogen fertilisation. Semina: Ciências Agrárias, 38(4), 2337-2350. https://doi.org/10.5433/1679-0359.2017v38n4SUPLp2337

Pessoa, L. G. M., Oliveira, E. E. M., Freire, M. B. G. S., Freire, F. J., Miranda, M. A., \& Santos, R. L. (2010). Composição química e salinidade do lixiviado em dois solos cultivados com cebola irrigada com água salina. Revista Brasileira de Ciências Agrárias, 5, 406-412. https://doi.org/10.5039/agraria.v5i3a573 
Ponte, L. F. A., Ferreira, O. S., Alves, F. A. L., Ferreira-Silva, S. L., Pereira, V. L. A., \& Silveira, J. D. (2011). Variabilidade de indicadores fisiológicos de resistência à salinidade entre genótipos de cajueiro-anão e gigante. Pesquisa Agropecuária Brasileira, 46(1), 1-8. https://doi.org/10.1590/S0100-204X2011000100001

Prakash, O., Kumar, R., Mishra, A., \& Gupta, R. (2009). Artocarpus heterophyllus (Jackfruit): An Overview. Pharmacognosy Reviews, 3(6), 353-358.

Richards, L. A. (1954). Diagnosis and Improvement of Saline Alkali Soils, Agriculture, 160, Handbook 60. US Department of Agriculture, Washington DC. Retrieved from https://www.ars.usda.gov/ARSU/20360/ hb60_pdf/complete.pdf

Rodrigues, R. M., Cavalcante, L. F., Souto, A. G. L., Gheyi, H. V. R., \& Mesquita, F. O. (2017). Growth and regrowth of neem after cutting in saline-sodic soil treated with organic inputs. Revista Caatinga, 30(1), 116-124. https://doi.org/10.1590/1983-21252017v30n113rc

Sá, F. V. S., Brito, M. E. B., Melo, A. S., Antônio Neto, P., Fernandes, P. D., \& Ferreira, I. B. (2013). Produção de mudas de mamoeiro irrigadas com água salina. Revista Brasileira Engenharia Agrícola e Ambiental, 17(10), 1047-1054. https://doi.org/10.1590/S1415-43662013001000004

Sá, F. V. S., Brito, M. E. B., Figueiredo, L. C., Melo, A. S., Silva, L. A., \& Moreira, R. C. L. (2017). Biochemical components and dry matter of lemon and mandarin hybrids under salt stress. Revista Brasileira de Engenharia Agrícola e Ambiental, 21(4), 249-253. https://doi.org/10.1590/1807-1929/agriambi.v21n4 p249-253

Santos, D. B., Machado, M. S., Bispo, A. S. R., Santos, A. F. J., \& Aráujo, A. F. (2012). Desenvolvimento de alimento fermentado tipo "chucrute" com a utilização de bagunço (eixo floral) de jaca (Artocarpus integrifolia L.). Enciclopédia Biosfera-Centro Científico Conhecer, 8(15), 590-596.

Santos, R. V., Cavalcante, L. F., Vital, A. F. M., Lacerda, C. F., Souza, E. R., \& Lima, G. S. (2016). Interação salinidade-fertilidade do solo. In H. R. Gheyi, N. S. Dias, C. F. Lacerda, E. Gomes Filho (Eds.), Manejo da salinidade na agricultura: Estudos básicos e aplicados (p. 504). Fortaleza: INCTSal.

Silva, A. F., Pinto, J. M., França, C. R. R. S., Fernandes, S. C., Gomes, T. C. A., Silva, M. S. L., \& Matos, A. N. B. (2007). Preparo e uso de biofertilizantes líquidos. Comunicado Técnico, 130, 4.

Simões, D., Silva, R. B. G., \& Silva, M. R. (2012). Composição do substrato sobre o desenvolvimento, qualidade e custo de produção de mudas de Eucalyptus grandis Hill ex. Maiden $\times$ Eucalyptus urophylla $\mathrm{s}$. T. Blake. Ciência Florestal, 22(1), 91-100. https://doi.org/10.5902/198050985082

Taiz, L., Zeiger, E., Moller, I. M., \& Murphy, A. (2017). Fisiologia vegetal (6th ed., p. 818). Porto Alegre: Artmed.

\section{Copyrights}

Copyright for this article is retained by the author(s), with first publication rights granted to the journal.

This is an open-access article distributed under the terms and conditions of the Creative Commons Attribution license (http://creativecommons.org/licenses/by/4.0/). 